\title{
Current status of plastic production, prospects and training of manpower in Bangladesh
}

\author{
Dr. Md. Serajul Islam ${ }^{1}$, Engr. Md. Mahmudul Hasan ${ }^{1,2}$ and Engr. Md. Mosaddeque Hossain ${ }^{3}$ \\ ${ }^{1}$ Department of Chemical Engineering, Bangladesh University of Engineering and Technology (BUET) \\ ${ }^{2}$ Chief Executive Officer (CEO) ACT Energy \& Power \\ ${ }^{3}$ Chairman, Chemical Engineering Division, The Institutions of Engineers, Bangladesh and Project \\ Director, MOI, Bangladesh Petroleum Corporation.
}

\begin{abstract}
The main strategy for achieving accelerating growth and reducing poverty, income inequality and regional disparity include creation of productive employment in the manufacturing and organized service sector is to accelerate trade and investment in each and every sector. Development of small and medium enterprises (SMEs) is envisaged as a key element in this strategy. In this aspect, a survey on 43 plastic factories, 5 mold industries, 5 importers of plastic raw materials and machineries, 5 National \& International Industries (RMG, Leather and plastic Sectors), 2 Association (BGMEA \& BPGMEA) \& 3 Government Agencies (Export Promotion Bureau (EPB), Ministry of Labor \& Empowerment and Bangladesh Technical Education Board (BTEB)) was conducted on the name of "Need assessment to set-up Bangladesh Institute of Plastic Engineering \& Technology (BIPET)". SMEF and BPGMEA offered this study on plastic sector. The plastic factories surveyed included micro, small, medium and large factories. About $80 \%$ factories belonged to the SMEs. Technical persons in the Management positions were interviewed using detailed questionnaire. The questionnaire was set to analyze the present status of production process, existing working conditions, hiring trends, education-training-technical skillsworking experience of workers and technicians, wages framework, troubleshooting problems, types of machine, technology level, training facilities, need for testing, product quality, research \& development facilities, existing factory owner's qualification, their demand and facing challenges by entrepreneur \& future prospect of plastic production in Bangladesh. Key recommendation for the development and future prospect of this sector is to support newly established Bangladesh Institute of Plastic Engineering \& Technology under the supervision of BPGMEA and technical assistance from BUET.
\end{abstract}

Keywords: Plastic, Engineering; Prospects; SMEs and BIPET

\section{Introduction}

The plastics industry has developed considerably since the invention of various routes for the production of polymers from petrochemical sources. Plastics have substantial benefits in terms of their low weight, durability, lower cost which can readily be molded into a variety of products that find use in a wide range of applications. From 1980, Bangladesh's plastic sector is growing from a cottage industry to heavy industries. Innovative entrepreneurship and diversification, plastic products have now joined the league of textiles, apparel, leather and jute goods, lucrative packaging, bottle, rigid sheet, PVC pipe with engineering equipment, furniture, health, educational and agricultural uses etc. Today, plastic sector has around 5000 small, medium and large size plastic goods manufacturing units with around 1 million workforces directly or indirectly employed in this sector.

At present total consumption of imported polymers and recycled plastic waste is more than 750,000 metric tons each year and it is continuously growing. Bangladesh is a developing nation and is yet to achieve world-class standard in many items of plastic products. Plastics industry lack in modern technology; capital resources are limited compared to many developed countries. Newly stated Bangladesh Institute of Plastic Engineering \& Technology (BIPET) has already conducted professional training for developing skill manpower. This study was conducted to identify the present status of plastic sector by surveying 43 plastic factories, 5 mold industries, 5 importers, 3 national and international institutes.

\section{Salient Feature of Plastic Industries}

Plastic is used to manufacture a wide variety of products in several engineering process to meet the domestic demand in Bangladesh as well as some products are exported. The plastic industry has emerged as an important industrial sector in the country during more than the last two decades with a potentiality to become a large global player in plastic industry, although it has not yet emerged as

Corresponding author: Engr. Md. Mahmudul Hasan

Email: emonhasan038@gmail.com, eh@emonhasan.com 
a global player in the segment. Plastic products were introduced in Bangladesh, in the latter half of the 1940s. Significant growth in plastics sector took place during the last two decades after the introduction of the free market in 1990's. At present, thereare about 5,000 plastic industries in the country of which 3,500 are small and 1,480 are medium \& 20 are large sized. But there are some factories which are basically micro level including two to five employees. The plastics sector has employed approximately 1.2 million people with investment of 185.5 billion BDT. Development of plastic sector is gradually changed from the year 1960 's to present as shown in table-1.

Table-1: Milestones of Development of Plastic Industries in Bangladesh

\begin{tabular}{ll}
\hline Year & Technology \& Products \\
\hline 1960 's & $\begin{array}{l}\text { Technology: Manual, handmade mold } \\
\text { Products: Small products such as toys, } \\
\text { bangles and photo frame were made using } \\
\text { handmade molds. Plastic spare parts for } \\
\text { jute mills. }\end{array}$ \\
1970 's & $\begin{array}{l}\text { Technology: Introducing injection grade } \\
\text { Products: Developed new products as } \\
\text { household. Plastic jugs and plate are the } \\
\text { example of it. }\end{array}$ \\
1980 's $\begin{array}{l}\text { Technology: Injection grade and film } \\
\text { blowing grade } \\
\text { Products: Plastic Bag \& related packet for } \\
\text { packaging industries }\end{array}$
\end{tabular}

1990's Technology: Film \& injection blow molding, injection, locally produced mold but not critical

Products: RMG accessories like hangers, Knob, button, electrical equipment etc.

2000's Technology: Higher \& sophisticated injection molding, Rotational molding, locally developed recycling machines (shredder, extruder, pelletizer), mold production by CNC machine

Products: Plastic chairs and tables, water tank made by rotation molding, bag knob, lock etc.

2010's Technology: Highly sophisticated \& automated, imported CNC machines with automation

Products: food grade plastic product, mobile phone, parts of car etc.

Retail packaging (cosmetics and industrial packages; woven sacks, garbage bags, butcher bags, industrial films, polythene sheets, plastic hangers, gloves, ropes, freezer bags, etc.), industrial and bulk packaging (woven sacks for food grain, chemical, fertilizer, cement, poultry food, rain protectors, green-house films, etc.), household uses (tableware and kitchenware, pet bottle, chair, table, bathtub, jug, mug, bucket, container, food box, flasks, plates, glasses, spoons, soap case, toilet brush, pan, toys, artificial flowers, clock, etc.) office equipment (ball pen, marker, paperweight, scale, desk calendar, File cover etc., building materials (door, windows frame, pipes, pipe fittings, electric cables, electric switches, water tanks etc., engineering parts \& industrial parts (cone, bobbin, silver can, screw, containers, drums, plastic spare parts for machinery etc., medical instruments (blood bag, medicine container, injection, saline bag, medicine packages etc., agricultural Products (plastic pipe, dram seeder etc., poultry \& fishing (pot, Jar, fishing net, fishing ball, egg crate, fish crate etc.), automobile \& cycle parts (cars bumper, handle grieve cover, back light, spoke light, dash board etc. , electronics (calculator, plaque, holder, multi plaque, regulator, cables, fridge and TV parts, etc., Textile Articles (polyester yarn), Engineering Products: Accessories for electronic products, etc., musical products (video/audio CD, DVD players, etc. ) eta are the basic products that's are produced by the plastic industries. Presently world market is trying to change all products material into plastic made. But highly technological advanced plastic goods are not produced in Bangladesh due to lack of technical support and unskilled labor. Survey on production basis, approximately, $50-60 \%$ per cent of plastics are used for single-use disposable applications, such as packaging, agricultural films and disposable consumer items, between 20 and $25 \%$ for long-term infrastructure such as pipes, cable coatings and structural materials, and the remainder for durable consumer applications with intermediate lifespan, such as in electronic goods, furniture, vehicles, etc. Over 5000 Plastic Manufacturing units are currently operating and most of these are small-scale (about 70 per cent) and domestic market-oriented. Nearly about 250300 units are currently involved in the export market. (source: BPGMEA).

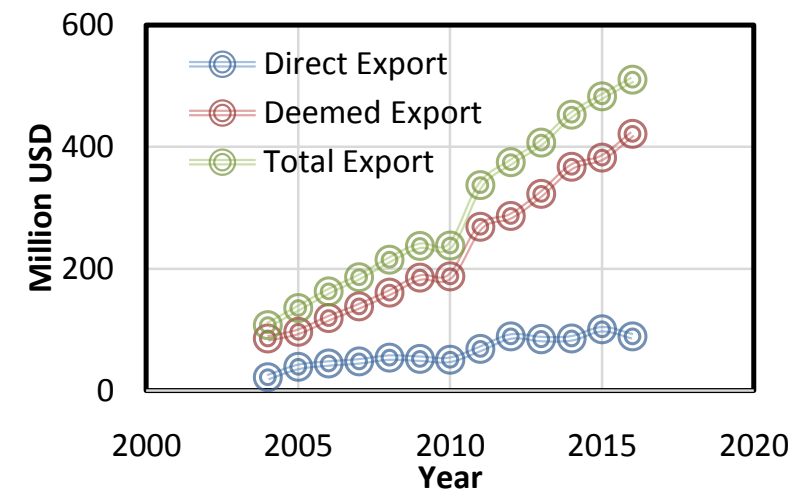

Fig.1: Trends of income from the export (direct, deemed $\&$ total) of plastic products

Export performance of Bangladesh in the recent past has been somewhat gloomy as based on data from Export Promotion Bureau. During July- 
December 2016, Bangladesh's exports grew by only 4.4 percent which was targeted to achieve a growth of 8 percent. Export growth of readymade garments was 4.4 percent and of non-RMG 4.8 percent - both remained quite low compared to their respective growth targets of 8.1 and 7.4 percent for FY 2017. This is disappointing since the country aspires to reach a USD 60 billion export target by 2021. Plastic goods are exported directly to Poland, China, UK, Belgium, France, Germany, USA, Canada, Spain, India, Nepal, Bhutan, Australia, Sri Lanka, Japan, Malaysia, UAE, Hong Kong, Bahrain, Italy, New Zealand, Netherlands, etc.

Bangladesh, at present, has a share of 0.01 percent of the global plastic market that measure up to $\$ 599$ billion, according to a recent report of the Center of Policy Dialogue (CPD). But it is alarming that export earnings of plastic sector are largely depending on RMG section named deemed export. Deemed exports refer mainly to plastic products as accessories to apparel.

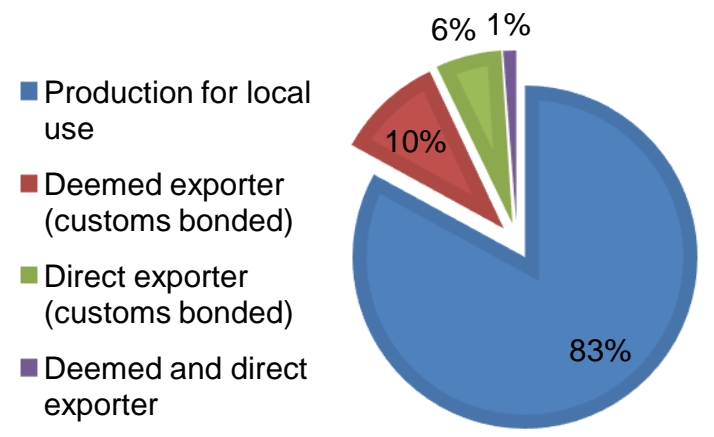

Fig.2: Market orientation of plastic factories in Bangladesh

Gradually increasing of plastic market as shown in Fig.2, it is clearly observed that Bangladesh is growing as a global player. During the FY 2015-16, production of plastic products for domestic market is 2.5 billion US dollar, where as direct and deemed exports are about 89 and 421.41 million US dollar respectively.

Only $1 \%$ factory have capacity to maintain the international quality for both direct and deemed export whether $6 \%$ factory have capacity only for direct export. But $10 \%$ factories have capacity for maintaining the international standard for deemed export. However, by Deemed export was 421.41 million USD for the FY 2015-16. Which indicates it is huge potential to attain this market. Deemed export is depending on RMG export mostly. But direct export of plastic was decreased by $11.5 \%$ of its growth and $24.58 \%$ of its export target. Bangladesh can expand its share globally but the reasons for failing to take benefit from advantageous market conditions are the supply constraints and unskilled workforce in the sector and also other factors as described in previous.

\section{Survey Findings:}

In Bangladesh about $98 \%$ factories belong to SMEs and rest are large. But in our survey $81 \%$ of SMEs and $18 \%$ for large (Micro- employees' number up to 10 , small- employees' number 10 to 50 , mediumemployees' number 51 to 300 , large- employees' number is over 300)sampling because of reliable and availability of data's. The most dramatic result of the data collection effort is the similarity among all factories in terms of challenges and needs which confirmed the hypothesis that many plastics factories within the region share similar operating conditions such as regulatory requirements, training needs, economic conditions, competitive forces and raw material needs. Summary of findings are listed in Table.2:

\section{Limitations}

There are more than 5,000 plastic factories are operating in Bangladesh but only 43 plastic factories were chosen for survey because of time, budget constraints, time frame and some unavoidable circumstances. On the other hand, large factory numbers are proportionally high for getting more reliable technical information.

Only plastic factory owners and higher officials were interviewed during the survey. However, despite severe time and resource constraints, the use of multiple primary research instruments (e.g., field visits, depth interviews with key informants and focused group discussions) helped to gain very effective and meaningful information.

\section{Recommendations}

Based on analysis of the survey findings of this study, several recommendations are provided to address the need assessment to set up BIPET and also additional activities to develop the plastic sector.

a) Training Module:

i. Due to lack of educational background of most of the employees, the training language should be in Bengali and academic curriculum should be according to educational background. On the other hand, training should be focused on the survey-identified topics.

ii. As to training method it should be on-the-job training using suitable instructor for the current workers. New recruits are to be trained in the plastic training institute.

iii. Training class should be under the digital supporting's 
Table-2: Major Findings of Current Status with Facing Challenges by Entrepreneurs \& Future prospect of Plastic Sector in Bangladesh.

\begin{tabular}{|c|c|c|c|}
\hline \multicolumn{2}{|c|}{ Major Issue } & Details & Observations \\
\hline \multicolumn{4}{|c|}{ Source: Statistical data: Export Promotion Bureau, BGMEA and BPGMEA } \\
\hline \multirow{3}{*}{$\begin{array}{l}\text { Export } \\
\text { Earnings } \\
\text { of Plastic } \\
\text { Sector }\end{array}$} & $\begin{array}{l}\text { Target VS } \\
\text { performanc } \\
\text { e of Direct } \\
\text { Export }\end{array}$ & $\begin{array}{l}\text { During the FY 2014-15 DE increased } 11.47 \% \\
\text { over export target } \\
\text { - During FY 2012-13 \& 2013-14, performance DE } \\
\text { was bellow the target DE } \\
\text { - During the FY } 2012-13 \text { performance DE growth } \\
\text { rate was decreased by } 4.71 \%\end{array}$ & $\begin{array}{l}\text { Political stability is one } \\
\text { of the major issue for } \\
\text { business development }\end{array}$ \\
\hline & \begin{tabular}{|l} 
Deemed \\
Export
\end{tabular} & $\begin{array}{l}\text { - During the last } 13 \text { years deeded export is } \\
\text { gradually increased with the supporting's of } \\
\text { RMG sector ( } \$ 85.29 \text { to } \$ 421.41 \text { million) } \\
\text { - FY } 2015-16 \text {,it was } \$ 421.41 \text {. }\end{array}$ & $\begin{array}{l}\text { - Its impact is more } \\
\text { than direct export on } \\
\text { GDP } \\
\text { - It is accounted for } \\
\text { more than } 75 \% \text { of } \\
\text { total export }\end{array}$ \\
\hline & $\begin{array}{l}\text { \% plastic } \\
\text { export to } \\
\text { the total } \\
\text { export }\end{array}$ & $\begin{array}{l}\text { - During the last } 13 \text { years plastic export is } \\
\text { average } 1.5 \% \text { to the total export of Bangladesh }\end{array}$ & $\begin{array}{l}\text { Plastic sector will pay a } \\
\text { very import role on GDP }\end{array}$ \\
\hline \multicolumn{2}{|c|}{$\begin{array}{l}\text { Plastic Product } \\
\text { development }\end{array}$} & $\begin{array}{l}\text { - Plastic product from hand made mold to } \\
\text { automatic molding is changed from the year } \\
1970 \text { s to 2000's. }\end{array}$ & $\begin{array}{l}\text { Research should be } \\
\text { organized for } \\
\text { product development }\end{array}$ \\
\hline \multicolumn{2}{|c|}{$\begin{array}{l}\text { Location of Plastic } \\
\text { Industries }\end{array}$} & $\begin{array}{l}\text { - The capital city Dhaka owns } 65 \% \text { plastic } \\
\text { industries whether } 20 \% \text { for Chittagong, } 10 \% \text { for } \\
\text { Narayangonj and } 5 \% \text { for others. }\end{array}$ & $\begin{array}{l}\text { Strategy should change } \\
\text { for decentralization } \\
\text { policy. }\end{array}$ \\
\hline \multicolumn{2}{|c|}{$\begin{array}{l}\text { Import of polymer } \\
\text { Granules }\end{array}$} & $\begin{array}{l}\text { - During the period } 1989 \text { to } 2007 \text {, the import of } \\
\text { polymers increased from } 10,000 \text { tons to } \\
289,000 \text { tons per year. } \\
\text { At present total consumption of polymers } \\
\text { including imported polymers and recycled } \\
\text { plastic wastes is } 750,000 \text { tons in FY } 2010-2011 \text {. }\end{array}$ & $\begin{array}{l}\text { Should make a common } \\
\text { platform for everyone to } \\
\text { easy access of virgin } \\
\text { material }\end{array}$ \\
\hline \multicolumn{2}{|c|}{$\begin{array}{l}\text { Capital Investment or } \\
\text { Banking Support }\end{array}$} & $\begin{array}{l}\text { Bangladesh Bank Incentives } \\
\text { - Export Development Fund (EDF) Fund: All } \\
\text { member units of the Bangladesh Plastic Goods } \\
\text { Manufacturers \& Exporters Association } \\
\text { (BPGMEA) can now take maximum USD } 1 \\
\text { million as loan from EDF fund. Presently it is } \\
\text { increased up to USD } 1.5 \text { billion with a special } \\
\text { interest rate (London Interbank Offered Rate } \\
\text { (LIBOR)) } 2.5 \% \text { to further assist the country's } \\
\text { export sector. } \\
\text { Foreign Loan Access: Bangladesh Bank also } \\
\text { allows some large private companies like RFL } \\
\text { Plastic Limited to get USD } 15 \text { million borrowing } \\
\text { from external sources. } \\
\text { Start Up financing: New entrepreneurs can take } \\
\text { up to BDT } 10 \text { lakh as collateral-free loans at } \\
\text { maximum } 10 \% \text { interest rate under a new } \\
\text { initiative by the central bank. However, with } \\
\text { collateral an entrepreneur can avail up to BDT } \\
25 \text { lakh as loan. }\end{array}$ & $\begin{array}{l}\text { - Interest rate should } \\
\text { be in single digit for } \\
\text { a startup business } \\
\text { - Should open a fund } \\
\text { for some innovative } \\
\text { project on plastic at } \\
\text { a very small interest } \\
\text { loan. }\end{array}$ \\
\hline
\end{tabular}


Table-2: Major Findings of Current Status with Facing Challenges by Entrepreneurs \& Future prospect of Plastic Sector in Bangladesh. (Cont.)

\begin{tabular}{|c|c|c|}
\hline Major Issue & Details & Observations \\
\hline \multicolumn{3}{|c|}{ Source: Plastic Factories \& Mold Industries } \\
\hline \multirow[b]{5}{*}{$\begin{array}{l}\text { Starting Period of } \\
\text { the Business }\end{array}$} & \multirow{5}{*}{$\begin{array}{l}\text { Fig.3: Starting Period of Plastic industries } \\
\text { Although plastic industry came to Bangladesh in the } \\
\text { 1980s the trend for that business in a large scale is } \\
\text { relatively much more recent. More than 80\% of the } \\
\text { industry units that we surveyed started operating in } \\
\text { 1990s, majority of them were within 10 years. }\end{array}$} & \multirow{5}{*}{$\begin{array}{l}\text { Presently entrepreneur } \\
\text { of this field is not } \\
\text { increased with the rate } \\
\text { of demand of plastic } \\
\text { products. }\end{array}$} \\
\hline & & \\
\hline & & \\
\hline & & \\
\hline & & \\
\hline $\begin{array}{l}\text { Expansion of } \\
\text { factory }\end{array}$ & $\begin{array}{l}\text { For the increasing rate of demand of plastic goods in } \\
\text { domestic and international market, most of the survey } \\
\text { respondents has plan for expansion of it. But it is } \\
\text { alarming that some small factory owners are not in } \\
\text { feasible condition neither in quality nor at safety for the } \\
\text { expansion of it because of political unrest condition. }\end{array}$ & $\begin{array}{l}\text { Government should give } \\
\text { some support for the } \\
\text { development of small } \\
\text { entrepreneur. }\end{array}$ \\
\hline $\begin{array}{l}\text { Gender Ratio of } \\
\text { Entrepreneurs }\end{array}$ & $\begin{array}{l}\text { - Ignoring the sampling error, } 100 \% \text { owners are male. So } \\
\text { it is evident that female are not comfortable in this } \\
\text { business relating with environment. }\end{array}$ & $\begin{array}{l}\text { Female entrepreneur } \\
\text { should come with } \\
\text { changing the working } \\
\text { environment. }\end{array}$ \\
\hline $\begin{array}{l}\text { Forms of } \\
\text { ownership }\end{array}$ & $\begin{array}{l}\text { - Most of the plastic industry units are either sole- } \\
\text { proprietorships or partnerships. Family owned } \\
\text { partnerships are also prevalent. }\end{array}$ & $\begin{array}{l}\text { Partnership business } \\
\text { have a huge prospect. }\end{array}$ \\
\hline $\begin{array}{l}\text { Issue of company } \\
\text { registration }\end{array}$ & $\begin{array}{l}\text { - Initially for surveying we select } 60 \text { companies for } \\
\text { surveying but } 17 \mathrm{~s} \text { were cancelled for reason } \\
\text { registration and time bindings. }\end{array}$ & $\begin{array}{l}\text { Government losses VAT } \\
\text { \& Tax. }\end{array}$ \\
\hline $\begin{array}{l}\text { Business } \\
\text { Experience of the } \\
\text { entrepreneur }\end{array}$ & $\begin{array}{l}\text { - About } 70 \% \text { of the owners were previously engaged in } \\
\text { another job before turning to this profession. }\end{array}$ & $\begin{array}{l}\text { Business experience } \\
\text { should be needed for } \\
\text { more development. }\end{array}$ \\
\hline $\begin{array}{l}\text { Reasons for } \\
\text { Starting the } \\
\text { Business }\end{array}$ & $\begin{array}{l}\text { - Most of the owners pointed financial self-sufficiency as } \\
\text { the key reason } \\
\text { - } 70 \% \text { of the respondents identified financial incipiency } \\
\text { as the primary reason } \\
\text { - } 23 \% \text { said failure to find employment }\end{array}$ & $\begin{array}{l}\text { Self-sufficiency is the } \\
\text { key but risk is also huge. }\end{array}$ \\
\hline $\begin{array}{l}\text { Capital invested } \\
\text { primarily }\end{array}$ & $\begin{array}{l}\text { - The amount of capital investment is too much high } \\
\text { and varied a great deal, mainly with the product type. } \\
\text { - The total investment of the SME based industry varied } \\
\text { from Tk. } 15,00,000 \text { to more than Tk. } 30,00,000 \text { lakh. } \\
\text { But high range is really expensive. }\end{array}$ & $\begin{array}{l}\text { Government should give } \\
\text { a capital inspective for } \\
\text { the development of this } \\
\text { field. }\end{array}$ \\
\hline $\begin{array}{l}\text { Sources of Initial } \\
\text { Capital }\end{array}$ & $\begin{array}{l}\text { - Almost all the owners said that the capital was acquired } \\
\text { from own or family sources. } \\
\text { - Big company have this source from Bank. }\end{array}$ & $\begin{array}{l}\text { Bank should give } \\
\text { support to all category of } \\
\text { entrepreneur. }\end{array}$ \\
\hline Business Model & $\begin{array}{l}\text { - Micro \& Small plastic company's business model is } \\
\text { Contract Manufacturing (CM) \& Low quality Own Account } \\
\text { Manufacturing (OAM); Medium plastic company's } \\
\text { business model is OAM \& CM; Large good quality OAM } \\
\text { - CM \& OAM is } 23 \% \text {, only CM } 58 \% \text { \& only AM is } 19 \% \text { of the } \\
\text { survey respondents }\end{array}$ & $\begin{array}{l}\text { Quality of product should } \\
\text { be improved }\end{array}$ \\
\hline
\end{tabular}


Table-2: Major Findings of Current Status with Facing Challenges by Entrepreneurs \& Future prospect of Plastic Sector in Bangladesh. (Cont.)

\begin{tabular}{|c|c|c|}
\hline Major Issue & Details & Observations \\
\hline $\begin{array}{l}\text { Age variation } \\
\text { for } \\
\text { entrepreneur }\end{array}$ & $\begin{array}{l}\text { Fig.4. Age Variation for Entrepreneur } \\
\text { Because of a healthy mount of initial investment, very young } \\
\text { entrepreneurs are found rarely. Most owners of the plastic } \\
\text { industries show a trend to engage in the industry in their late 30s } \\
\text { and early 40s. }\end{array}$ & $\begin{array}{l}\text { Government should } \\
\text { give some support for } \\
\text { the young } \\
\text { entrepreneur for the } \\
\text { development of it. }\end{array}$ \\
\hline $\begin{array}{l}\text { Age variation } \\
\text { for workers }\end{array}$ & $\begin{array}{l}\text { Most of the labor of factory have average age limit is } 20 \text { to } 35 \text {. } \\
\text { But on the other hand here child labor is visible in these } \\
\text { industries. }\end{array}$ & $\begin{array}{l}\text { Child labor should be } \\
\text { prohibited. }\end{array}$ \\
\hline $\begin{array}{l}\text { Educational } \\
\text { Qualification } \\
\text { of } \\
\text { entrepreneur }\end{array}$ & $\begin{array}{l}\text { Bellow class } 5 \mathrm{SSC} \text { HSC Honurse Masters } \\
\text { Educational Qualification Level }\end{array}$ & $\begin{array}{l}\text { Educated people } \\
\text { should come on this } \\
\text { business for the more } \\
\text { development. }\end{array}$ \\
\hline $\begin{array}{l}\text { Plastic based } \\
\text { product }\end{array}$ & $\begin{array}{l}1829 \text { types of plastic product were found in survey where almost } \\
2,500 \text { types of plastic products are available in Bangladesh. }\end{array}$ & $\begin{array}{l}\text { In the household } \\
\text { segment, more } \\
\text { expensive wood-based } \\
\text { products can be } \\
\text { replaced by less costly } \\
\text { plastic products. }\end{array}$ \\
\hline $\begin{array}{l}\text { Capabilities of } \\
\text { identifying } \\
\text { technical } \\
\text { problems }\end{array}$ & $\begin{array}{l}\text { Approximately } 60 \% \text { of the respondents from factories do not } \\
\text { have the ability to identify technical problems. Nearly all large } \\
\text { factories ( } 19 \% \text { of respondents) have some capability of } \\
\text { identifying of problems whereas medium size factories have only } \\
\text { limited ones. }\end{array}$ & $\begin{array}{l}\text { Wastage of time and } \\
\text { money }\end{array}$ \\
\hline Mold Used & $\begin{array}{l}\text { - Mostly micro \& small companies used local of low quality, } \\
\text { medium companies used mostly local and imported and large } \\
\text { companies imported only. } \\
\text { - A very few companies have own automated mold house. }\end{array}$ & $\begin{array}{l}\text { Mold industries should } \\
\text { be in automation } \\
\text { technology }\end{array}$ \\
\hline Recycling & $\begin{array}{l}\text { - In the year } 2010,60 \% \text { of the post use plastic waste was } \\
\text { recycled in the country resulting in a saving of USD } 600 \\
\text { million saving on import of virgin materials. } \\
\text { - Only } 3 \% \text { respondent use directly only plastic waste raw } \\
\text { materials as recycling. Where } 37 \% \text { for non-virgin materials, } \\
40 \% \text { for virgin materials and } 16 \% \text { for virgin and non-virgin } \\
\text { materials. } \\
\text { - Almost all factory used the recycled from machine rejected. }\end{array}$ & $\begin{array}{l}\text { Recycling technology } \\
\text { should adopt in a } \\
\text { innovative way with } \\
\text { good quality of } \\
\text { product. }\end{array}$ \\
\hline
\end{tabular}


Table-2: Major Findings of Current Status with Facing Challenges by Entrepreneurs \& Future prospect of Plastic Sector in Bangladesh. (Cont.)

\begin{tabular}{|c|c|c|}
\hline Major Issue & Details & Observations \\
\hline $\begin{array}{l}\text { Lack of } \\
\text { educational } \\
\text { qualification of } \\
\text { workers }\end{array}$ &  & $\begin{array}{l}\text { Because of low } \\
\text { educational } \\
\text { background, } \\
\text { worker } \\
\text { productivity is low } \\
\text { and chances of } \\
\text { accidents are } \\
\text { increased }\end{array}$ \\
\hline $\begin{array}{l}\text { Method of } \\
\text { training }\end{array}$ & $\begin{array}{l}\text { - } 36 \% \text { of the respondents from factories would like to avail short } \\
\text { courses; } \\
19 \% \text { opted for formal in-house training provided by external } \\
\text { trainers, while } 17 \% \text { chose apprenticeship, } 17 \% \text { asked for full } \\
\text { time training and } 11 \% \text { for on-the-job training }\end{array}$ & $\begin{array}{l}\text { Employers find it } \\
\text { tough to train } \\
\text { worker those have } \\
\text { low educational } \\
\text { background }\end{array}$ \\
\hline \multirow[t]{2}{*}{$\begin{array}{l}\text { Training Topics } \\
\text { for worker }\end{array}$} &  & $\begin{array}{l}\text { Topics to be } \\
\text { covered: } \\
\text { Machine set-up } \\
\text { Machine operation } \\
\text { Machine } \\
\text { maintanence } \\
\text { Quality assurance } \\
\text { Quality control } \\
\text { Lab techniques } \\
\text { Mold design }\end{array}$ \\
\hline & $\begin{array}{l}\qquad \begin{array}{c}20 \\
\text { Number of Factories }\end{array} \\
\text { Fig.7 : Technical Skill Focus for Training } \\
\text { Basic training module for workers should be prepared and } \\
\text { conducted in Bangla. Different types of educational background } \\
\text { need to be taken into consideration during the preparation of the } \\
\text { following training modules: a) Plastic processing techniques } \\
\text { b) Material handling and c) Quality control and assurance }\end{array}$ & \\
\hline $\begin{array}{l}\text { Willingness to } \\
\text { hire trained } \\
\text { worker }\end{array}$ & $\begin{array}{l}\text { Approximately } 95 \% \text { respondents have shown their willingness to } \\
\text { send their workers for training or want to hire trained workers. } \\
\text { Nearly all respondents gave their opinion in favor of setting up of a } \\
\text { training institute which will address the training and other services } \\
\text { needs of the plastics sector }\end{array}$ & $\begin{array}{l}\text { Will send workers } \\
\text { for training if it is } \\
\text { fruitful and also } \\
\text { meet their } \\
\text { requirements }\end{array}$ \\
\hline
\end{tabular}

b) Technological advanced research:

BIPET should start some research for the development of plastic field. Especially plastic related innovative products. BIPET can offer some research related to innovation of product with engineering faculty at BUET. c) Entrepreneur Training: For the development of this field there should be a provision of entrepreneur training on this field.

d) Enrich Business Strategy: Plastics industry is now working as a backward linkage industry for many growing industries, especially the RMG 
and pharmaceuticals, has created a lot of opportunities for value added within the country. If more forward linkage industries such as food processing, agriculture, automotive, electrical and electronics develop and mature, the plastics sector will experience a robust growth. Conversely, if the plastics sector becomes competitive, these forward linkage industries will enjoy cost advantage.

e) Innovation Competition: SME Foundation should offer a innovation competition program for come out the young generation and also the development of this field.

f) Raw Materials: It is important to source the raw materials for all type plastic factories (micro, small, medium \& Large) from a common platform.

g) Registration of All Companies: Starting the business needs lots of paper work and formalities if done properly. It should be stricked for doing this business by proper registration formalities.

h) Single Digit Loan Facilities: Government should give a support for a single digit loan to reduce the initial pressure of new business venture.

i) Industrial Zone: First of all Government should create a secluded industrial zone for plastic industries with gas and electricity and other supplies and transfer all the industries there.

j) Taxation Fascilities: Government should remove taxation on the plastic sector for at least a five-year period to give the growing industries a chance. In the case of PVC pipe, toys, food based products etc. manufacturers, the government has imposed VAT, which is affecting the industry very much. So the government should exempt VAT for all new PVC pipe industry for at least five years.

k) Regirstration Rules \& Regulation: Most of the small enterprises are not following the rules and regulations, which eventually hampers the business. BPGMEA should be strict for giving their certification.

I) Minimum Education Level: BIPET can arrange at least a minimum education qualification for the entrepreneur and also the worker.

\section{Conclusion}

The economy of Bangladesh is a developing one that is classified as a next eleven emerging market and one of the Frontier Five with GDP growth is $6.2 \%$ over the past five years. Where this is increasingly led by export-oriented industrialization. In 2015, per-capita income stood at USD 1,314 which also indicates the improvement in living standards of the people. With this spur the plastic industry growth is also increasing. Domestic demand is mainly supported by large population, growing middle class \& strong forward linkage industry. Direct Export growth rate on the $F Y$ is $17.37 \%$ where as Deemed Export growth rate is only $4.08 \%$. Vision 21 target is to reach the turnover for plastic sector will of USD 4 billion by 2021 . This survey finding will give a big support if the recommendations will take by the government to reach this goal.

\section{References}

1. Karl M. Kapp, Ed.D. CFPIM, CIRM, 'Need Assessment of the Plasticlndustries in Central Pennsylvania' A study for Central Pennsylvania workforce Development Corporation. (July 30, 2004)

2. Shahedul Islam Helal, "Concept of Plastic in Bangladesh", 2002

3. M. S. Islam, "Opportunity and Challenges of Plastic Sector in Bangladesh", A study for SME Foundation, 2012

4. M. S. Islam "Introduction to Plastics, Manufacturing Technology and Recycling of Waste Plastics", 2013

5. Rafiqul Islam, "Study on Control and Management of Polyethylene Bags in Bangladesh", A study for Department of Environment, MOEF, GoB; study by SMEC Bangladesh, 2001

6. Nagorik Committee, "Bangladesh Vision for 202 Centre for Policy Dialogue (CPD), 2006

7. Nagorik Committee, "Bangladesh: Visison for 2021"

8. Country Studies on Bangladesh, Srilanka and Nepal; Annex-I, Country Studies on Bangladesh using global Value Chain Analysis: The Plastic Industries; Un-Escap Report, 2012

9. R. A. Malatest\& Associates Limited, "Training Need Analysis for the Canadian Plastic Sector Council" a study for Canadian Plastic Sector Council, 2011

10. M. Serajul Islam, M. M. Hasan "Current status of Plastic Production and Training of Manpower in Bangladesh" Souvenir of $8^{\text {th }}$ International Fair, 2015

11. Need Assessment to set-up Bangladesh Institute of Plastic Engineering \& Technology", International Plastic Fair, 2014

12. M. Serajul Islam, M. M. Hasan "Need Assessment to set-up Bangladesh Institute of Plastic Engineering \& Technology", Souvenir of $8^{\text {th }}$ International Fair, 2014

13. "Ijaz Hossain, Plastic waste "Plastic waste management in Bangladesh International Plastic Fair, 2008.

14. M. S. Islam, Prospect and challenges of plastic industries in Bangladesh", Journal of Chemical Engineering, Vol. ChE. 26, No. 1, December 2011, IEB

15. "Plastic in Various Field" Sayed Baquer Hossain, Plastic \& Polymer, Souvenir of Plastic Fair, 2004

16. SME Foundation, National Consultation Report on SME Development of Six Booster Sector, 2013 